This is the authors' version of the final accepted manuscript published subsequently in Ecological Economics: https://doi.org/10.1016/j.ecolecon.2018.01.007. Elsevier(C) 2017. This manuscript version is made available under the CC-BY-NC-ND 4.o license.

\title{
Global governance of resources and implications for resource efficiency in Europe
}

Ben Milligana,* , Michelle O'Keeffe ${ }^{b}$

a Centre for Law and Environment, Faculty of Laws, University College London, Bentham House, Endsleigh Gardens, WC1H oEG, United Kingdom

b UCL Institute for Sustainable Resources, University College London, Central House, 14 Upper Woburn Place, London WC1H oNN, United Kingdom

Corresponding author: b.milligan@ucl.ac.uk. An earlier version of this paper was prepared as a contribution to a UN Environment International Resource Panel report to the G7 Summit, Ise-Shima Japan, May 26-27 2016. Preparation of the paper was supported by funding provided by UN Environment (M1-32ECL-000008) and the European Commission (FP7 ID 308371).

\begin{abstract}
Consumption and production of natural resources in Europe is associated with increasingly globalised dependencies and impacts. It is crucial in this context that any national and regional policy reform efforts in Europe - designed to increase the efficiency of resource consumption and production - recognise the global contexts that they interact with and within which they are embedded. Responding to a subset of this awareness challenge, we present here a coarse-grained survey of the multi-level global governance architecture relevant to the consumption and production of natural resources. We identify key structural features of global governance that function as barriers to resource efficiency, and emergent responses to these barriers that policy reform efforts in Europe could continue to build on and support.

\section{Introduction}

Policy decision-making in Europe and generally is shaped by, and embedded within, a complex global web of relationships between individuals and institutions. Global governance refers to the many ways that individuals and institutions, public and private, manage their common affairs in this context (CGG, 1995, Dingwerth and Pattberg, 2006, Weiss and Thakur, 2010, Donahue and Nye Jr., 2000). Global
\end{abstract}


governance of resources is a process characterised by a wide variety of actors, normative frameworks, hierarchical relationships, and associated spatial boundaries (Young, 1997, Speth and Haas, 2009, Biermann and Pattberg, 2008). These components are summarised below and illustrated in Figure 1.

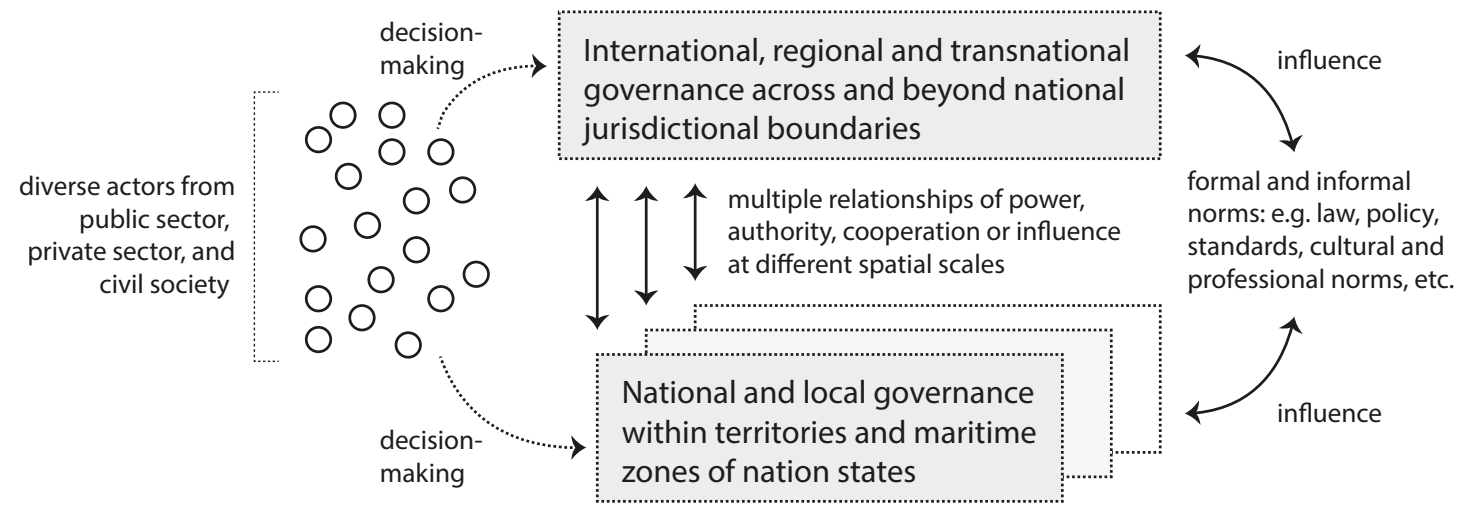

Figure 1: Key components of global resources governance. Source: Authors.

Actors - The actors that participate in global resources governance include but are not limited to governments, intergovernmental organisations (IGOs), private entities from commercial and non-profit sectors, and diverse communities within civil society (Biermann and Pattberg, 2008, EEA, 2011, Levy and Newell, 2004). Each of these actors pursues different sets of interests at different spatial scales, in different social, cultural, political, economic and environmental contexts (Harris, 2016).

Normative frameworks - Decision-making by different actors concerning resources is enabled, constrained and influenced by a wide variety of normative frameworks (Bodansky et al., 2007, Pattberg, 2005, Young et al., 2008). These frameworks have varying degrees of formality. More formal normative frameworks include treaties, laws, regulations, policies, contractual agreements and technical standards (Hunter et al., 2015, Morrison and Roht-Arriaza, 2007). Less formal normative frameworks include administrative, commercial, professional, cultural and interpersonal practices.

Behavioural relationships - Both actors and normative frameworks are influenced and shaped by relationships of power, authority, cooperation or influence at multiple levels (Newig and Fritsch, 2009, Bache and Flinders, 2004, Weibust and Meadowcroft, 2014). These relationships are often described as vertical when they are predominantly hierarchical, horizontal when they are predominantly cooperative and voluntary.

Spatial boundaries - Different actors and normative frameworks shape global resources governance at different spatial scales, including local, national, regional and international. As explained in more detail below, the spatial boundaries of governance at each of these scales is often not aligned with the biophysical and spatial characteristics of resources. Many resources straddle, migrate across, or are affected biophysically by 
activity located beyond jurisdictional boundaries (Benvenisti, 2002, Kliot et al., 2001). Many resources are also moved across jurisdictional boundaries, through various interconnected and globalised supply and value chains (WTO, 2014, OECD et al., 2014). The participation of entities other than national governments (e.g. corporations) in decision-making about resources that transcends national jurisdictional boundaries is commonly described as transnational in character (Betsill and Bulkeley, 2004).

Using the components outlined above as an analytical template, this article presents a coarse-grained survey of key features of global resources governance, highlighting the significant ways in which they both enable and constrain efforts by different actors - including but not limited to those located in Europe - to consume and produce resources more efficiently. It also identifies several promising ways in which global resources governance is beginning to respond to the urgent need to improve resource efficiency - including through protection and definition of resource-related rights; coordinated management of resources and resource-related impacts across sectors, boundaries and globalised value chains; and recognition of the multiple public and private benefits of resources. These responses are apparent in Europe and elsewhere at local, national, regional and global scales. An important policy challenge for the European Union, national and subnational governments, and other actors located in Europe, is to ensure that governance barriers to resource efficiency are progressively addressed through continued cooperation, capacity development, and other forms of mutual support.

\section{Key features of global resources governance}

International law establishes a basic architecture of global resources governance through recognition of several general rights and obligations of nation states. These are summarised below and illustrated in Figure 2.

Resources on land - are subject to the permanent sovereignty of nation states within their respective territories (UNGA, 1962, Schrijver, 1997). The Convention on Biological Diversity (CBD, 1992) recognises that "States have, in accordance with the Charter of the United Nations and the principles of international law, the sovereign right to exploit their own resources pursuant to their own environmental policies, and the responsibility to ensure that activities within their jurisdiction or control do not cause damage to the environment of other States or of areas beyond the limits of national jurisdiction." The above principles divide rights and responsibilities concerning resources governance into exclusive and spatially discrete national units, except in the several locations (e.g. Antarctica) where multiple states currently assert overlapping claims to territorial sovereignty (CIA, 2016, Huth, 1998). 
Marine resources in zones of national jurisdiction - The United Nations Convention on the Law of the Sea (UNCLOS, 1982) recognises the sovereignty of coastal states over a Territorial Sea extending up to 12 nautical miles (NM) from baselines designated in accordance with the Convention, and over Archipelagic Waters claimed by certain archipelagic states. It also recognises certain exclusive sovereign rights and obligations of coastal states concerning resources located on their Continental Shelf, or in an Exclusive Economic Zone (EEZ) extending up to 200NM from relevant baselines. Many oceans and seas currently feature, and are characterised by, overlapping claims to sovereignty or exclusive sovereign rights concerning resources (Milligan, 2012). Less than half of the world's potential international maritime boundaries have been delimited (Prescott and Schofield, 2004, Schofield, 2011).

Marine resources located beyond zones of national jurisdiction - UNCLOS and associated agreements also recognise rights and obligations of states concerning resources located on the high seas and deep seabed (Warner, 2009). Resources in these zones (e.g. fisheries, poly-metallic nodules, genetic resources) are not subject to the sovereignty or sovereign rights of states, and are managed through cooperative frameworks including the International Seabed Authority, International Whaling Commission, and regional fisheries management organisations (RFMOs). Resources on the deep seabed are recognised as forming part of the "common heritage of mankind" (Baslar, 1998).

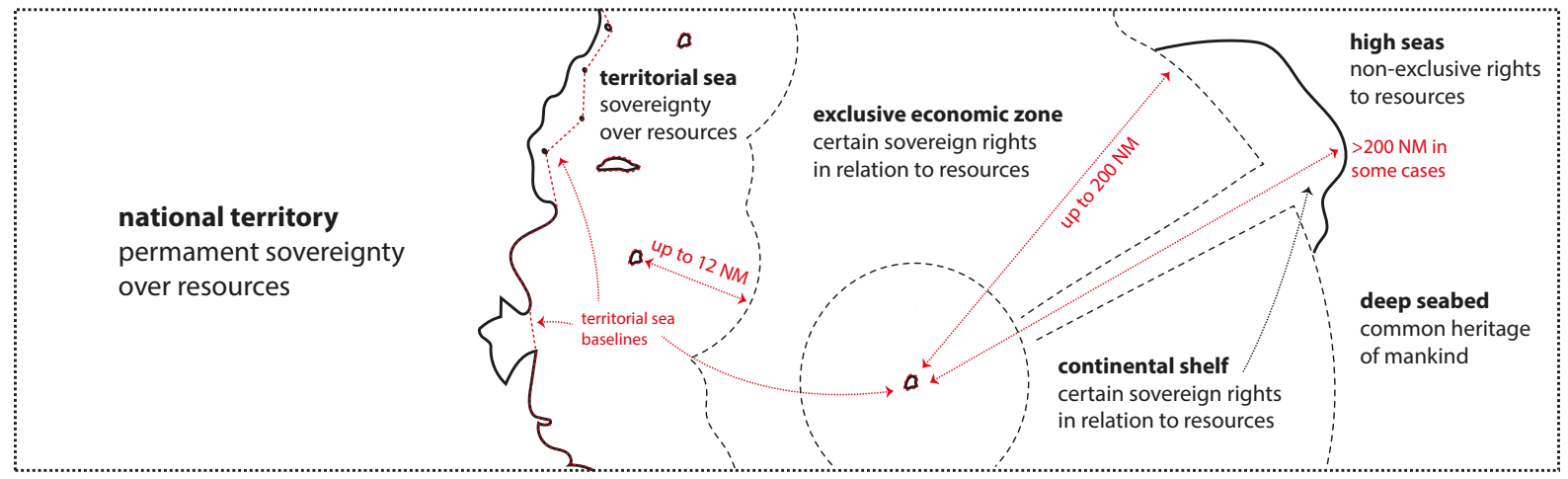

Figure 2: The basic architecture of global resources governance. Source: Authors, adapted from GeoSciences Australia, 2017.

Key features of global resources governance that have been established within this basic architecture are summarised below, at national (including local), regional and international (including transnational) scales. Important implications for resource efficiency are then discussed in Section 3. 


\subsection{National resources governance}

The actors who participate in resources governance within the territories and maritime zones of nation states include government institutions, commercial and non-profit entities from the private sector including subsets of transnational entities, and communities of interest within civil society. The behaviour of these actors influences, and is influenced by, national laws, policies, customs and other norms whose content varies considerably from country to country. Common formal normative features of resources governance at a national scale include the following:

Roles, responsibilities and organisation of government - National laws and constitutions generally define the major roles and responsibilities of government in relation to resources, and allocate these to different government institutions including parliaments, executive agencies, and the judiciary. Government institutions are commonly established at multiple nested levels of scale, with certain responsibilities allocated to regional or local governments. In countries that are organised federally (e.g. Australia, Brazil, Canada, Germany, India, Mexico and the United States), responsibilities concerning resources are divided between the national government and those of partially self-governing sub-national territories. The responsibilities of executive governments concerning resources are also commonly divided along sectoral lines - e.g. through creation of separate ministries responsible for energy, mining, forestry, fisheries, agriculture, water resources, and/or environmental management.

Management and development of resources - Government agencies in many countries have established detailed policy frameworks concerning management and development of their resources and allocation of associated benefits. Conventionally these are focused on particular sectors (e.g. extractive industries, agriculture, water, fisheries and aquaculture) with limited integration across sectors. In recent decades, national policy frameworks concerning resources have increasingly focused on various important crosscutting issues, including: livelihoods, poverty and human rights (Young and Goldman, 2015, IFAD, 2011, Zillman et al., 2002, Toulmin and Quan, 2000, Ellis and Biggs, 2001); spatial and development planning (IPCC, 2014a, IPCC, 2014b, UN-Habitat, 2009, CBD and GEF, 2012); ecosystem-based management (UNEP, 2011); climate change mitigation and adaptation (IPCC, 2014a, IPCC, 2014b, Lim and Spanger-Siegfried, 2004); the resource nexus (Kurian and Ardakanian, 2015, UN-ESCAP, 2013); the green economy (OECD, 2012, OECD et al., 2012, UNDESA, 2012); resource efficiency (UNEP, 2014b, EC, 2011b); and sustainable development (UNDESA, 2015). Noteworthy examples relating specifically to resource efficiency are discussed further in Section 3 below. 
Rights concerning resources - National legal systems in Europe and elsewhere recognise a wide variety of exclusive or non-exclusive rights (and corresponding obligations) concerning resources, including property rights (Hanna et al., 1996, McHarg et al., 2010, Barnes, 2009, Aggarwal and Elbow, 2006). Key property rights that are recognised in each country in different bundled groups include: withdrawal (right to obtain products of a resource); management (right to regulate internal use patterns and transform the resource by making improvements); alteration (right to change the set of goods and services provided by a resource); exclusion (right to determine who will have an access right, and how that right may be transferred); and alienation (right to sell or lease some or all rights) (Schlager and Ostrom, 1992).

Limitations concerning resources - National legal systems also establish a wide variety of limitations on how rights concerning resources are exercised in different circumstances. Interactions with natural resources are for example limited by: spatial and development planning; prior authorisation requirements for the use and development of resources; reservation of resources for future use or strategic reasons; protected areas and other forms of spatial management (Dudley, 2008, Stolton et al., 2013); restrictions on certain interactions with protected species, habitats and ecosystems (Bowman et al., 2010); control measures concerning pollution; and procedural obligations including strategic and project-level environmental impact assessments (Craik, 2011). Generally, the purpose of such restrictions is to maintain or enhance public benefits of resources (e.g. drinking water supply, taxation income from resource rents) or the aggregate level of private benefits (e.g. through unitisation of petroleum deposits, or coordinated management of irrigation in agriculture).

The interaction of relevant rights, and limitations concerning how they are exercised, shapes societal expectations concerning resources and the allocation of resource-related benefits to support different public or private interests. Figure 3 maps in basic terms the variation of resource-related rights on two dimensions (degree of exclusivity, and limitation on how rights are exercised) across different national legal systems and key associated policy risks. These risks include low compliance with formally defined rights and limitations; underinvestment in resources management including for resource efficiency; exploitation of resources at unsustainable levels; inequitable allocation of benefits from resources. 


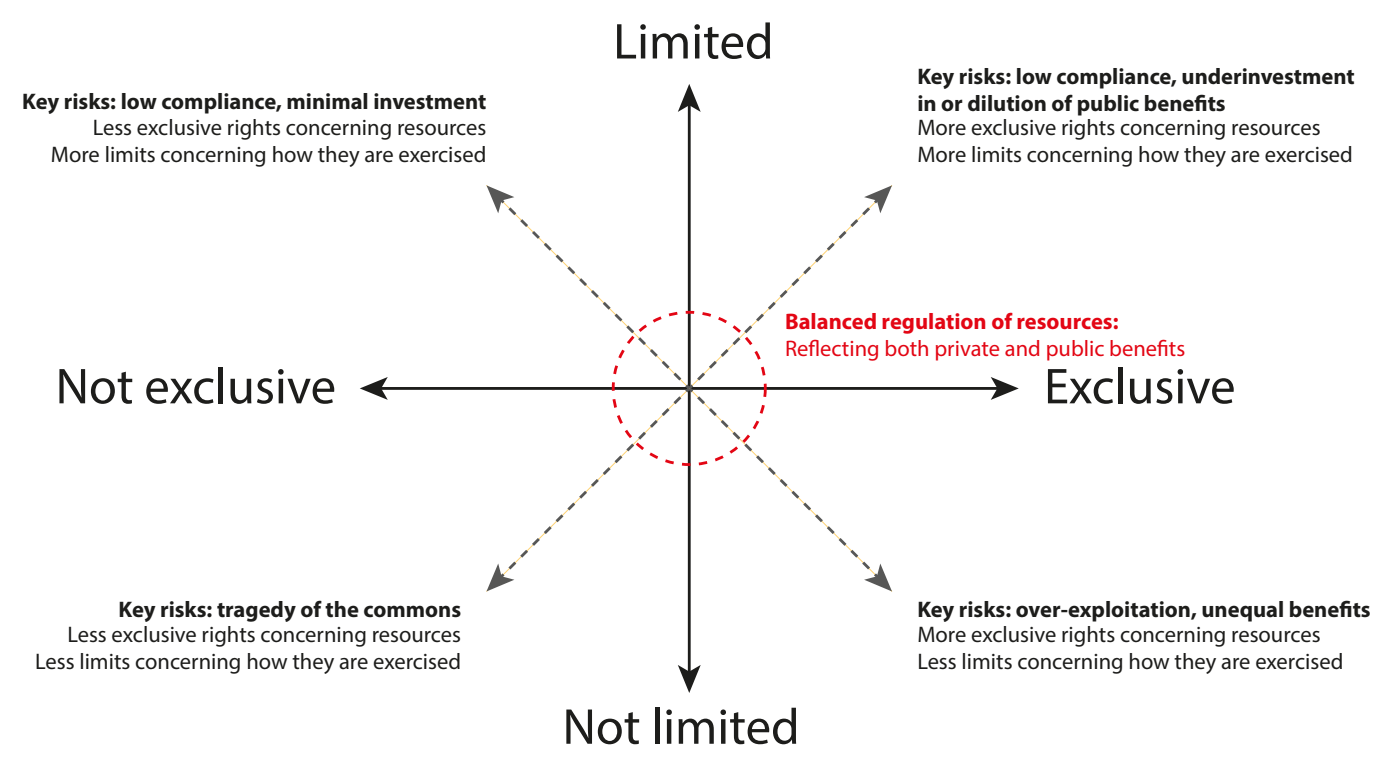

Figure 3: Variation of rights on two dimensions and key policy risks concerning resources. Source: Authors.

An important issue in several countries is the discrepancy between formally recognised rights to resources, and the resource-related expectations and dependencies of local communities (Toulmin and Quan, 2000). Many local communities around the world are highly dependent on resources (e.g. forests, fisheries, agricultural land) over which they do not enjoy formal property rights (Suárez et al., 2009, Palmer, 2012, RRI, 2015). Economic development policies in several low and middle income countries have in some cases facilitated the large-scale acquisition of formal property rights by commercial sector actors, including to enable mining and plantation agriculture (Cotula et al., 2009, Cotula et al., 2014). These acquisitions are often characterised by the involvement of transnational corporations (TNCs), including state-owned enterprises from other countries (Cotula, 2013, Holden and Pagel, 2013, UNCTAD, 2009). TNCs are comprised of national entities located in more than one country, linked together by ownership or otherwise, under a coherent system of decision-making in which they can exercise significant influence over each other and share knowledge, resources and responsibilities (Weissbrodt and Kruger, 2003, Sauvant, 2015).

Negative outcomes associated with large-scale property acquisition in low and middle income countries include: expropriation without adequate compensation of formal rights held by individuals and communities; extinguishment of long-standing informal rights held by individuals and communities; dislocation of local communities from acquired areas; destruction of local livelihoods; and resources development that maximises marketable private benefits (e.g. timber extraction) to the detriment of public benefits (e.g. access to clean water) (Anseeuw et al., 2012). Promising initiatives designed to address these challenges are summarised in Section 3. 
In many contexts the spatial scale of resources, and impacts of economic activity on resources, extend across national boundaries. For example, approximately 40 per cent of the world's population lives in river and lake basins comprised of two or more countries (UN-Water, 2008) and many living resources (e.g. fish stocks) migrate across national boundaries. Key biophysical spatial interactions between resources and national boundaries are illustrated in Figure 4.

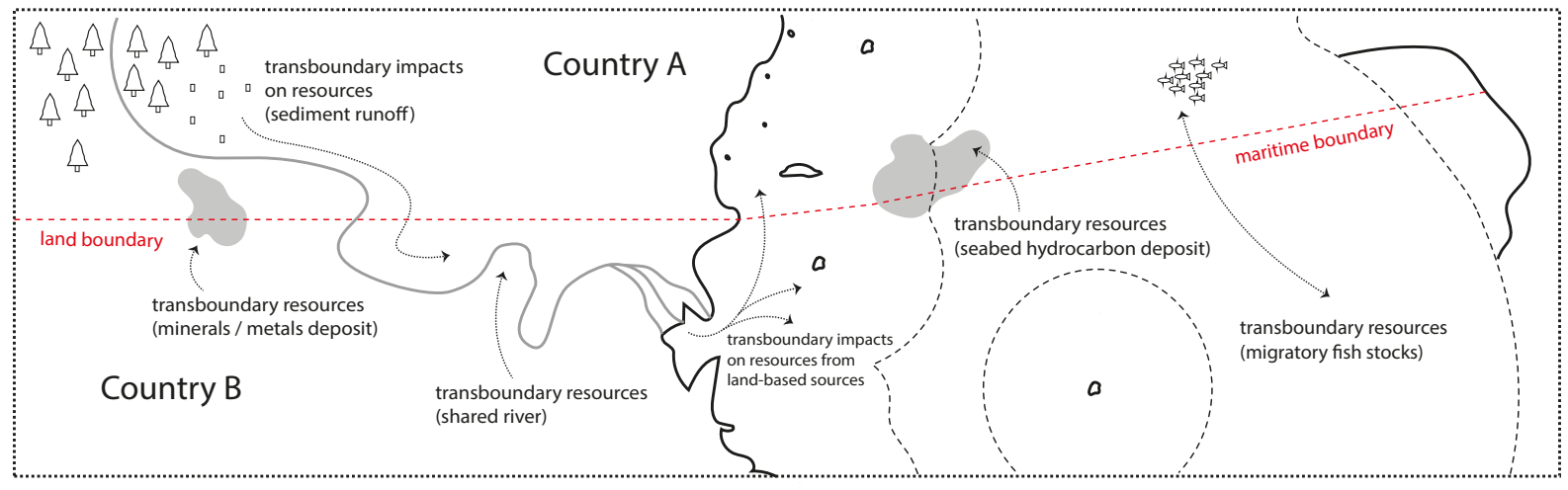

Figure 4: Key biophysical interactions between resources and national boundaries. Source: Authors.

The movement of resources across national boundaries is also driven by the increasing organisation of production, trade and investment into globalised supply and value chains (OECD et al., 2014, Kaplinsky and Morris, 2001). These chains have diverse characteristics -including different degrees of complexity, fragmentation, interconnectedness, and resource intensity, and different structures of control and ownership (OECD, 2013). Figure 5 provides simplified examples of supply and value chains in the extractive sector (adapted from Dicken (2011)) and agricultural sector (adapted from Dolan and Humphrey (2000) and Dicken (2011)). These examples are illustrative of how many supply and value chains for resources are characterised by interactions between multiple actors across multiple countries. 

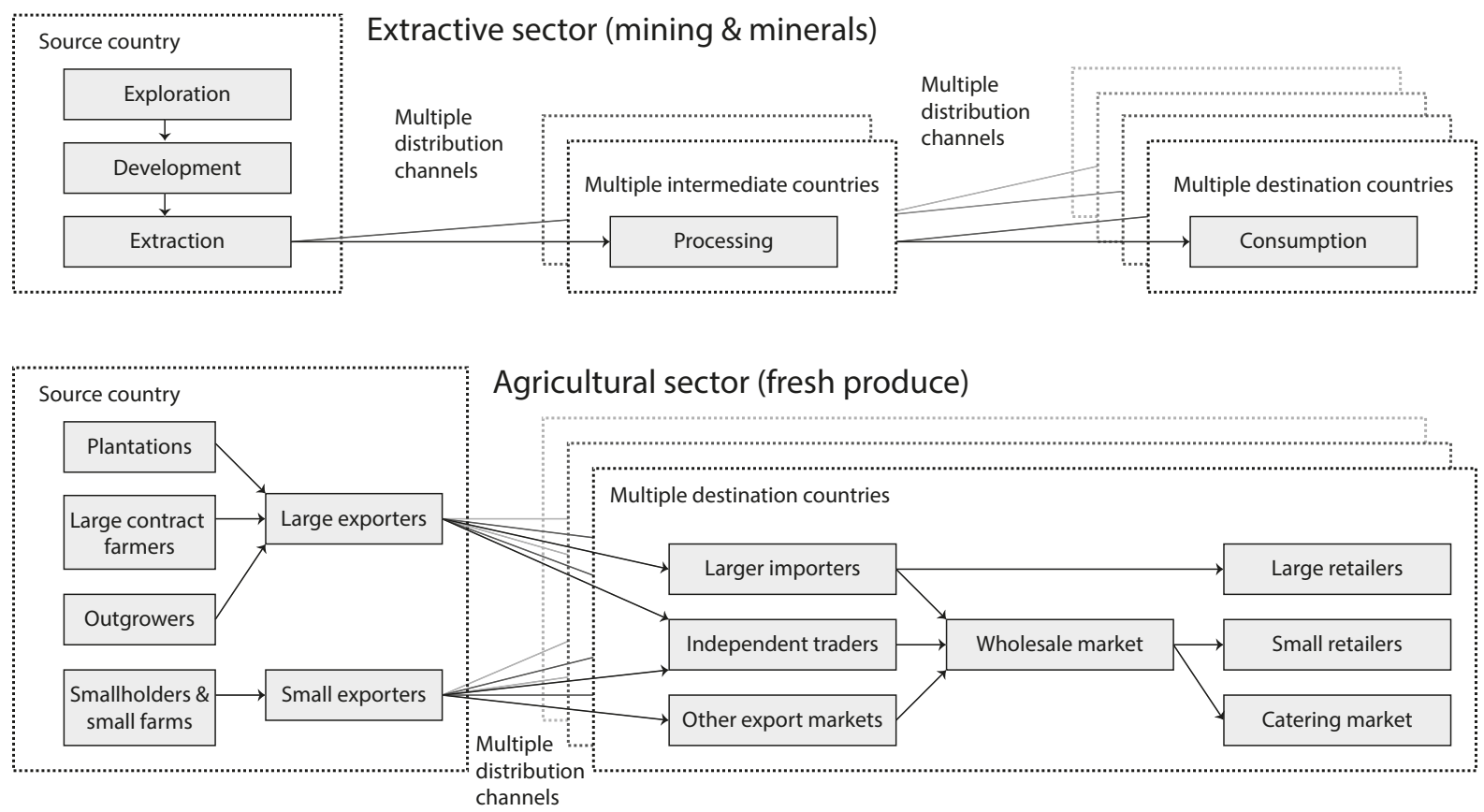

Figure 5: Illustrative structures of global supply and value chains for resources. Source: Authors, adapted from Dolan and Humphrey (2000) and Dicken (2011).

Efficient use of resources across national boundaries and globalised value chains depends on cooperation between relevant actors at regional (e.g. within the European Union) and international scales. Sections 2.2 and 2.3 provide a broad overview of actors who participate in resources governance at these scales, and key normative frameworks in Europe and elsewhere that have been established with a view to coordinating the activities of these actors.

\section{$2.2 \quad$ Regional resources governance}

The actors participating in resources governance at a regional level include national governments, regionally and internationally-focused IGOs, private transnational entities operating on a commercial or non-profit basis, and regional communities of interest within civil society. Key coordination frameworks involving different combinations of these actors include the following:

Management of resources and the environment - Regional inter-state agreements in this field have proliferated in recent decades, focusing on management of: shared rivers and water resources (Benvenisti, 2002, Kliot et al., 2001); marine resources in particular fisheries (Russell and Vanderzwaag, 2010); marine and terrestrial transboundary pollution (Birnie et al., 2009, Hunter et al., 2015); transboundary hydrocarbon resources including those subject to competing jurisdictional claims (Bastida et al., 2007, Weaver and Asmus, 2006); migratory species (Birnie et al., 2009, Hunter et al., 2015); and biodiversity conservation including through establishment of 
transboundary protected areas (Sandwith et al., 2001). Several of these agreements establish specialised institutions for regional resources governance - e.g. the South Pacific Regional Environment Programme, and OSPAR Commission for protecting the North-East Atlantic and its resources. Regional cooperation concerning resources and environmental management is also funded and brokered by several multilateral institutions, in particular the United Nations Environment Programme (UNEP) and Global Environment Facility (GEF). Several countries have agreed to manage the Antarctic continent and surrounding waters on a collaborative basis under the Antarctic Treaty System (Rothwell, 1996, Rose and Milligan, 2009).

Political and economic integration - Resources governance on every continent is influenced by agreements and institutions designed to foster regional economic integration. Key agreements and institutions include the: Andean Community of Nations; Association of Southeast-Asian Nations; Caribbean Community and Common Market; EU; North American Free Trade Agreement; Pacific Islands Forum; South Asian Association for Regional Cooperation; and Southern Common Market in Latin America. In the case of the EU, economic integration is accompanied by political and policy integration, including detailed legal and policy frameworks designed to improve resource efficiency (see Section 3.2).

Development finance - Resources governance is also influenced by the activities of regionally-focused development banks, including the: African Development Bank (AfDB); Asian Development Bank (AsDB); Development Bank of Latin-America; European Bank for Reconstruction and Development (EBRD); Inter-American Development Bank (IADB); and Islamic Development Bank. These multilateral institutions provide considerable financial and technical support to national and regional projects concerning resource efficiency. Examples include the AfDB Green Growth Framework (AfDB, 2014); AsDB Clean Energy Financing Partnership Facility and contributions to the $\mathrm{G} 8{ }_{3} \mathrm{R}$ Initiative on Waste management (see Section 3.2) (AsDB, 2008, AsDB, 2015); EBRD Sustainable Resource Initiative (EBRD, 2014); and IADB Energy Sector Framework (IADB, 2015).

\subsection{International resources governance}

The key actors participating in resources governance at an international level include national governments, private (i.e. non-government) transnational entities operating on a commercial or non-profit basis, and transnational communities of interest within civil society. Many activities of national governments relating to international resources governance are undertaken in institutionalised contexts, including under the auspices of the following IGOs: Principal Organs of the UN; UNEP; the UN Development Programme; Food and Agricultural Organisation of the UN (FAO); UN Industrial Development Organisation; Organisation for Economic Cooperation and Development 
(OECD); International Labour Organisation; World Trade Organisation (WTO); International Maritime Organisation; International Seabed Authority; World Bank Group; and GEF. A number of national governments also engage in international investment and commercial activity relating to resources via state-owned enterprises (Kowalski et al., 2013, UNCTAD, 2014).

The increasingly prominent and influential role of private transnational entities including transnational corporations (TNCs), not-for-profit organisations, and other formalised partnerships and associations - is a defining feature of international resources governance in recent decades (Braithwaite and Drahos, 2000, Pattberg, 2007, EEA, 2011). International resources governance is influenced by TNCs operating in and across all sectors of the economy. In 2009, activities of an estimated 82,000 TNCs with 810,000 foreign affiliates accounted for about a third of total world exports of goods and services by value (UNCTAD, 2009). The ability of TNCs to influence resource-related decision-making across globalised value chains depends on the governance structure of the chain in question. Different value chain structures afford different degrees of power and influence to TNCs. Figure 6 presents five illustrative modes of interaction between different private sector actors within globalised value chains, and corresponding degrees of power asymmetry and coordination (adapted from Gereffi et al., (2005)). "Market" value chains involve arms-length transactions between suppliers and customers. Coordination and information exchange between these actors is limited, and switching costs are low for both. In "modular" value chains, suppliers typically produce products according to the specification of a lead actor. Switching costs remain low as a result of coordination of production by intermediate "turn-key" suppliers, and technical standardisation. "Relational" value chains involve complex non-codified interactions between the lead actor and suppliers, and are characterised by mutual dependence, high levels of asset specificity, and higher switching costs for both actors. In "captive" value chains, small suppliers are transactionally dependent on lead buyers and face significant switching costs. "Hierarchy" value chains are characterised by vertical integration, with governance of subsidiaries and affiliates based on headquarters managerial control (Dicken, 2011). 


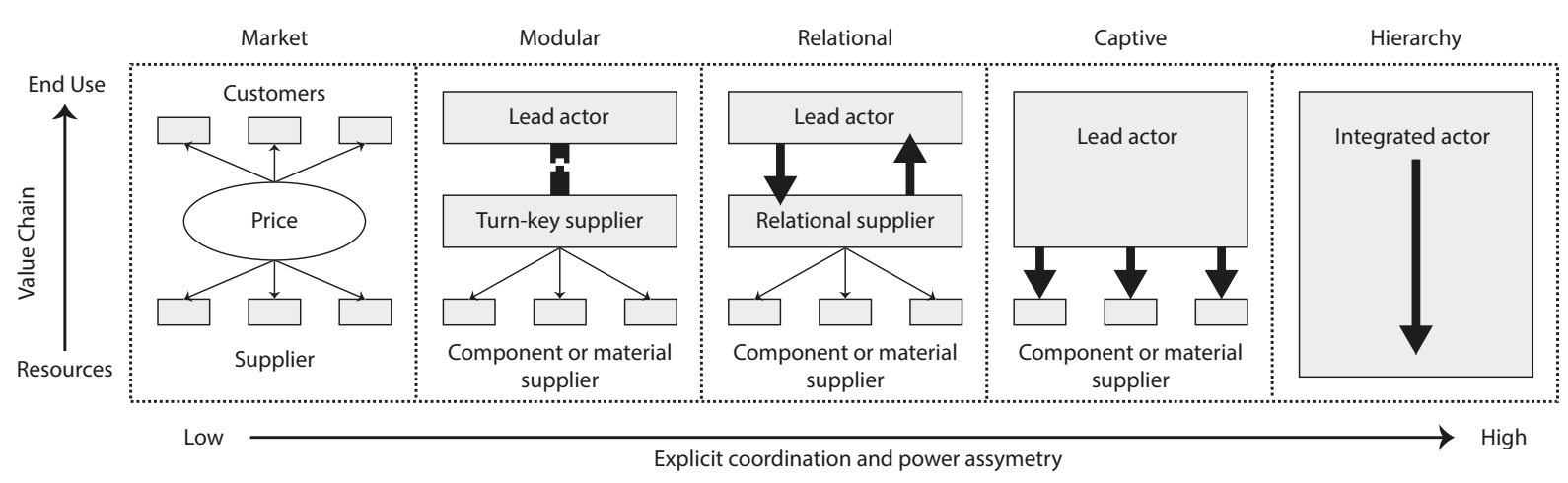

Figure 6: Illustrative modes of governance within global value chains for resources. Source: Authors, adapted from Gereffi et al., (2005).

A growing number of TNCs participate in collaborative networks designed to promote sustainable business within and across global value chains. Key focal points of collaboration concerning resource efficiency include the World Business Council for Sustainable Development (WBCSD); International Council for Mining and Metals; Global Alliance for Banking on Values; and Natural Capital Coalition.

Transnational not-for-profit organisations also influence international resources governance in a wide variety of capacities, including by: organising political and educational campaigns designed to influence normative frameworks; providing financial and technical support to resources management activities; acquiring property rights to resources; direct management of resources in partnership with relevant stakeholders; and convening dialogue between relevant stakeholders. Several not-for-profit organisations have truly global influence and reach (Spar and La Mure, 2003, Ahmed and Potter, 2006). For example, the membership of the International Union for Conservation of Nature (IUCN) includes 1000+ non-governmental organisations, 80+ nation states, $120+$ individual government agencies, and 11,000+ individual scientific experts from 185 countries (IUCN, 2014).

Another defining feature of contemporary international resources governance is the increasingly prominent and influential role of transnational communities of interest within civil society, which are characterised by the participation of decentralised and fluid combinations of individuals and organisations (Ghaus-Pasha, 2005, Gemmill and Bamidele-Izu, 2002). Global internet penetration and usage have increased dramatically in recent years. The global number of internet users has increased by more than 830 per cent since 2000, by more than 7200 per cent in Africa over the same period (ITU, 2015). Internet connectivity and social media have provided unprecedented opportunities for individuals, communities and organisations to act collectively at transnational scales. Key examples of transnational collective action relevant to resources include 350.org - a global network of campaigns for action to address climate change - and its fossil fuel divestment movement, which as of December 2015 has identified more than 500 
institutions representing over $\$ 3.4$ trillion in assets that have made some form of divestment commitment (350.org., 2015).

The activities of the actors summarised above influence, and are influenced by, a complex network of normative frameworks relevant to resources governance. Key examples of formal frameworks are summarised below:

The 2030 Agenda for Sustainable Development - Was adopted on 27 September 2015 by the 193 member states of the United Nations (UN, 2015). The Agenda features 17 Sustainable Development Goals (SDGs) and 169 associated targets, which UN member states have committed to implement by 2030. An important feature of the 2030 Agenda is its clear recognition that social and economic development depends on sustainable management of the natural environment and its resources. Concerning resource efficiency, the Agenda establishes targets relating to: increasing water efficiency (Targets 6.4); expanding international cooperation and capacity building support concerning water efficiency (6.a); doubling the global rate of improvement in energy efficiency by 2030 (7.3); enhancing international cooperation concerning energy efficiency research and technology (7.a.); progressive improvement of global resource efficiency in consumption and production, and decoupling of economic growth from environmental degradation in accordance with the 10-Year Framework of Programmes on Sustainable Consumption and Production (10YFP) (8.4); upgrading infrastructure and retrofitting industries with a view to increasing resource-use efficiency (9.4); substantially increasing the number of cities and human settlements adopting and implementing integrated policies and plans towards resource efficiency (11.b).

Multilateral agreements concerning the environment - These have proliferated in recent decades in a decentralised and ad hoc manner, responding to a wide range of specific environmental challenges (Kim, 2013, Hunter et al., 2015). The collective body of more than 700 multilateral environmental agreements (MEAs) is commonly described as a partial or "fragmented" response to challenges (e.g. resource efficiency) that are cross-sectoral or systemic in nature (Biermann et al., 2009, Kim, 2013). MEAs that touch on resource efficiency issues as a sub-component of other subject matter include the: UN Framework Convention on Climate Change (UNFCCC) and related instruments including the 2015 Paris Agreement; Convention on Biological Diversity and associated Aichi Biodiversity Targets; Ramsar Convention on Wetlands; FAO instruments concerning agriculture and fisheries; Basel Convention on the Control of Transboundary Movements of Hazardous Wastes and Their Disposal; Rotterdam Convention on the Prior Informed Consent Procedure for Certain Hazardous Chemicals and Pesticides in International Trade; Stockholm Convention on Persistent Organic Pollutants; UNCLOS and the supplementary UN Fish Stocks Agreement; and Vienna Convention for the Protection of the Ozone Layer. 
Multilateral agreements concerning trade and development - Key agreements include the: General Agreement on Tariffs and Trade, Agreement on Technical Barriers to Trade, and other agreements concluded under the auspices of the WTO; and the Cotonou Partnership Agreement between the EU and Africa, Caribbean and Pacific Group of States. A core objective of the WTO agreements is trade liberalisation, with a view to achieving more efficient use of the world's resource in accordance with the objective of sustainable development (WTO, 1994, WTO, 2015). Relevant objectives referred to in the Cotonou Agreement include: promotion of institutional reforms and development for efficient market economies (Article 20.d); preservation of the natural resource base (20.e); efficient maritime transport services in a safe and clean marine environment (42.1); and efficient exploitation of marine resources (84.c).

Multilateral agreements concerning human rights - These agreements establish various rights, obligations and dispute settlement mechanisms that affect decisionmaking by governments about resources (Bankes, 2010, Miranda, 2012). Relevant agreements include the International Covenant on Civil and Political Rights; International Covenant on Economic, Social and Cultural Rights; UN Declaration on the Rights of Indigenous Peoples; and the Aarhus Convention on Access to Information, Public Participation in Decision-Making and Access to Justice in Environmental Matters. These and similar agreements recognise and protect certain individual and community rights - relating generally to access and control of certain resources, and informed participation in resource-related decision-making (Zillman et al., 2002).

Bilateral or multilateral agreements concerning foreign investment - More than 3000 inter-state agreements relating to international investment have been concluded to date (UNCTAD, 2015). The general purpose of these international investment agreements (IIAs) is to ensure that states parties adhere to certain standards of treatment of foreign investors or investments (Salacuse, 2015, Gordon and Pohl, 2011). Many IIAs protect international investors by (1) obligating host countries to provide compensation for directly or indirectly expropriated assets, and/or (2) allowing foreign investors to settle disputes with host countries through compulsory and binding international arbitration (Van Harten, 2007).

Private standards relating to resources - Decision-making concerning resources is influenced by a wide variety of non-governmental standards, in particular those relating to technical specifications and performance; process and management; and measurement and reporting in different sectors (Morrison and Roht-Arriaza, 2007). Key examples relating specifically to resource efficiency are discussed further in Section 3. The development and adoption of private standards concerning resources is influenced by various factors including: demands of business partners and customers; reputational incentives; regulatory incentives; reduction of risks and liabilities; and commercial 
benefits associated with improved resource management (Morrison and Roht-Arriaza, 2007, Nikolaeva and Bicho, 2011, Henson and Reardon, 2005).

\section{Governance constraints on resource efficiency and promising responses}

The current architecture of global resources governance both enables and constrains efforts by different actors in Europe and beyond to use resources more efficiently. Current governance frameworks enable such efforts by allocating relevant rights and responsibilities to different actors, and by establishing frameworks for collaboration between these actors. However, several features of global governance currently constrain the ability of relevant actors to work together to use resources more efficiently in a manner that achieves sustainable and socially accepted flows of public and private benefits. Key governance constraints are outlined below, alongside selected promising efforts to address them at local, regional or international scales.

\subsection{Protection and definition of resource-related rights}

Resource efficiency is constrained in many contexts by the fact that rights and obligations concerning resources are not adequately defined, or are not protected in a manner that adequately balances public versus private benefits. Key manifestations of this constraint and several promising responses are summarised below:

Recognition of local community interests - As discussed in Section 2.1, in several countries there are discrepancies between formally recognised rights to resources, and the resource-related expectations and dependencies of local communities. Nonrecognition of community interests can disempower local action to improve resource efficiency - in particular where resource-related impacts are not appropriately regulated, or when resource rents are allocated predominantly to formal rights holders (e.g. to TNCs with formal resource development concessions). Promising responses to non-recognition of local community interests include: ongoing legal and policy reforms in several developing countries concerning individual and community land rights (RRI, 2016), incorporation of social and environmental impact assessments into regulatory decision-making (Vanclay et al., 2015), and sharing of resource rents with local communities (Barma et al., 2012); the FAO Voluntary Guidelines on the Responsible Governance of Tenure of Land, Fisheries and Forests in the Context of National Food Security (FAO, 2012); International Finance Corporation Performance Standards on Environmental and Social Sustainability; ILO Principles concerning multinational enterprises; UNEP Code of Ethics for Chemical Industries; and a growing range of private standards including the AA10oo Framework for stakeholder engagement; Kimberly Process Certification Scheme for diamonds; OECD Due Diligence Guidance on 
Responsible Supply Chains of minerals, and supplements; OECD Guidelines for Multinational Enterprises; ISO 26000 Social Responsibility Standard; Voluntary Principles on Security and Human Rights in the extractive sector; Revised Social Accountability 8000 Standard; ILO Principles concerning multinational enterprises; Equator Principles; Global Reporting Initiative Mining and Minerals Supplement; Conflict Free Gold Standard; and the Initiative for Responsible Mining Assurance.

Tensions between international investment agreements and national public interests A widely held concern in several countries is that foreign investor protections in IIAs, concerning indirect expropriation of investments and compulsory referral of disputes to binding arbitration, unduly constrain the ability of national governments to pursue environmental regulation in the public interest (Beharry and Kuritzky, 2015, UNCTAD, 2015). The prospect of an adverse award by an investment arbitration panel has been cited as an influential factor in several decisions by national governments to abandon or change ostensibly public interest regulations concerning the environment and natural resources (Gallagher and Shrestha, 2011, Tienhaara, 2011). Promising responses to address potential tensions between IIAs and national public interests include: the progressive integration of specific environmental and social protections into IIAs (Gordon and Pohl, 2011); the OECD Policy Framework for Investment (OECD, 2015); and the UNCTAD Core Principles for investment policymaking for sustainable development (UNCTAD, 2015).

Spatial mismatches between resources and rights concerning resources - Observed examples of spatial mismatches between resources and formally recognised resourcerelated rights include: fragmented property rights to ecosystems (Ruhl et al., 2007); conflicting or unclear superjacent property rights to the land surface and subsurface (Viet et al., 2013); conflicting or unclear rights concerning coastal and offshore areas (Yandle, 2007, Tompkins, 2008); and multiple concurrent or conflicting rights to a particular resource (Deininger and Ali, 2008). These mismatches can impact negatively on resource efficiency by impairing coordination between actors, and creating uncertainty and tensions that discourage investment by rights-holders in resource stewardship, including investments in resource efficiency. Promising responses to spatial mismatches between resources and resource-related rights are discussed in Section 3.2 .

Corruption - Resource governance in many countries is affected by varying degrees of regulatory capture, rent-seeking, bribery and illegal exchange, and other forms of corruption (Leite and Weidmann, 1999, Robbins, 2000, Kolstad and Søreide, 2009, Kolstad and Wiig, 2009). Corruption constrains resource efficiency by misallocating resources and resource rents, and by increasing costs of the allocation process itself (Liu et al., 2015, OECD, 2013). A related challenge is the pervasive lack in some countries of transparency and meaningful public participation, in government decision-making 
about resources and the impacts of these decisions on resource-related rights (Darby, 2010). Promising international efforts to reduce corruption and non-transparency in resource governance include the: UNDP Global Anti-Corruption Initiative (UNDP, 2014); Natural Resource Charter (NRGI, 2014); Public What You Pay Coalition; Extractive Industries Transparency Initiative; Council for Responsible Jewellery Practices; Global Reporting Initiative; Transparency Accountability Initiative; and the Open Government Initiative.

Capacity challenges - Governments, communities and individuals in many countries lack sufficient capacity to fully assert or enforce their resource-related rights and interests. Capacity challenges can be technical (e.g. availability of knowledge or qualified experts), social (e.g. level of awareness and education concerning certain issues), financial, or institutional (e.g. structural ability of institutions to coordinate certain action) in nature (UNDP, 2009, OECD, 2006). Resource governance that features capacity inequalities is at risk of producing distributively inefficient outcomes - e.g. where unequal bargaining power influences the allocation of resource rents in a manner that does not maximise aggregate social welfare. This risk is particularly acute in resource development contract negotiations between developing country governments and TNCs (Mitchell, 2013, Gilson, 2012). A wide range of public and private actors currently work to address these risks through diverse capacity building and disclosure initiatives. Illustrative examples include the Extractive Industries Transparency Initiative (Haufler, 2010), and IISD Guide to Negotiating Investment Contracts for Farmland and Water (Smaller, 2014).

\subsection{Coordination across sectors, boundaries and value chains}

Efforts to improve resource efficiency are also constrained by uncoordinated decisionmaking - by different actors, across spatial and sectoral boundaries, or across globalised value chains. A selection of promising responses to these constraints is highlighted below:

Coordinated and measurable action towards common goals - Global resource governance is increasingly informed by data, indicators and targets that enable diverse actors to assess and coordinate their progress towards common goals - including goals

relating to resource efficiency. Implementation of relevant goals and targets in the 2030 Agenda for Sustainable Development (see Section 2.3) will be underpinned by framework of indicators and statistical data designed to monitor implementation progress, inform policy development, and ensure accountability of all stakeholders (UNESC, 2015b). Development of this framework is coordinated by an Inter-Agency Expert Group on SDG Indicators, composed of UN Member States and including regional and international agencies as observers (UNESC, 2015a). At national and regional levels, resource-related data, targets, indicators and associated policy 
frameworks have proliferated in different policy domains, and across different economic sectors (Bahn-Walkowiak and Steger, 2015, GTZ et al., 2006). Illustrative examples include: "A resource-efficient Europe" - a Flagship initiative under the EU's Europe 2020 Strategy (EC, 2011b, EC, 2011a); China's 2009 Circular Economy Promotion Law and associated policies (West et al., 2013); and policies implemented under the United States Energy Independence and Security Act of 2007 (Fritsche et al., 2013). The European Commission has developed a "Resource efficiency scoreboard", including a suite of indicators designed to enable assessment of progress towards relevant EU policy goals (EC, 2015). An important challenge for accurate assessment of progress towards resource efficiency is the need to comprehensively account for the full range of costs, benefits and impacts associated with resource development and use. Promising measurement and accounting efforts to address this challenge are discussed in Section $3 \cdot 3$.

Coordination across spatial boundaries - A diverse range of resource-related transboundary cooperation agreements were surveyed in Section 2. Notwithstanding the promising progress that these represent, major gaps remain in cooperative resource management across spatial jurisdictional boundaries at national, regional and international scales. These gaps contribute to: inefficient use of land (UNEP, 2014a), water (UNEP, 2012b) and various other resources; transboundary pollution (Lee et al., 2016); uncoordinated regulation by governments of transnational actors; and tensions and conflict associated with competing or conflicting claims to resources (UNFT, 2012, Schofield, 2012). An illustrative example of scale of resource cooperation challenges is that 158 of the world's 263 transboundary water basins lack any type of cooperative management framework (WWAP, 2015). In addition to the international and regional examples discussed in Section 2, promising responses to spatial coordination challenges include the progressive implementation in a growing number of countries of: participatory spatial planning; catchment-based approaches to water governance; community and landscape-level land governance; and integrated coastal zone management.

Coordination across sectors - Efforts to improve resource efficiency are also impaired by the prevalence of decision-making isolated along sectoral lines. In many countries in Europe and elsewhere, governmental decision-making concerning resources is characterised by a multiplicity of sectoral mandates and institutions (e.g. agriculture, energy, water fisheries) which are not well coordinated or defined, or may overlap in relation to particular resources (Galaz et al., 2010, Charles, 2012). A related challenge is the prevalence of uncoordinated decision-making between public, private and third sector actors. At a national level, promising efforts to foster cross-sectoral coordination include growing range of: national institutions with specific cross-cutting or coordinating mandates; public administration procedures designed to develop "whole of government" and "participatory" decision-making; public participation frameworks (see 
Section 2); and integrative framing concepts such as "the resource nexus" (Ringler et al., 2013), "sustainable development", and "planetary boundaries" (Rockström et al., 2009), which are designed to transcend sectoral mandates and thereby establish a conceptual basis for cross-sectoral data management, objective-setting and decision-making. Coordination across sectors is also an important issue at multilateral level, with

decision-making being spread across the multiple institutions surveyed in Section 2, and influenced by the multiple surveyed normative frameworks. A promising development in this context is the emergence of "coherence" agendas - championed by UNEP, the Global Legislators Organisation, and others (UNEP, 2012a, UNEP, 2015). The principal aims of these are to ensure: (1) coordinated, efficient and mutually supportive operation of the multilateral institutions with mandates relating to sustainable development; and (2) coherent and mutually reinforcing implementation at a national level of key international agreements, including the UNFCCC, Sendai Framework for Disaster Risk Reduction, and the 2030 Agenda for Sustainable Development.

Coordination across value chains - Efforts to improve the resource efficiency of value chains are complicated in many cases by their complex globalised nature, internal power structures (see Section 2.3), and by the inability of involved actors to access accurate and complete information concerning resource dependencies in the relevant value chain(s). Governance of several global value chains is becoming more coordinated over time, in particular as a result of cross-sectoral collaboration between public, private and third sector actors. Relevant promising efforts in addition to those already identified in Section 3.1 include the: UN Global Compact; GRI Sustainability Reporting Guidelines; ICMM Sustainable Development Framework; Global E-sustainability Initiative; ICMM Toolkit; ISO/TC 207 concerning environmental management; ISO 14001 EMS standard; Standards for a Sustainable World; product certification schemes such as the Marine Stewardship Council and Forest Stewardship Council; and pollution-related standards such as the GHG Protocol and Verified Carbon Standard.

\subsection{Recognition of multiple benefits of resources}

Scientific and economic research has characterised, with increasing granularity, the physical stock of resources and their multiple contributions - many irreplaceable - to human well-being and development (MEA, 2005, Kumar, 2012, UK-NCC, 2013, Mace et al., 2015). The range of benefits provided to people by biotic and abiotic resources is illustrated in Figure 7. 


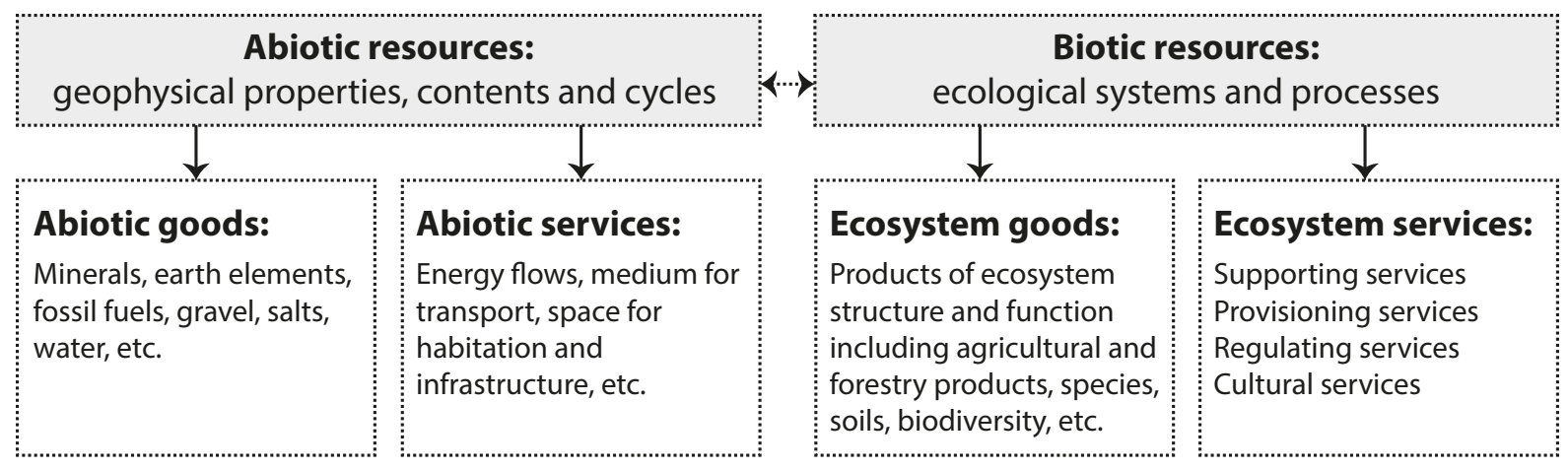

Figure 7: Multiple benefit flows from resources. Source: Authors, adapted from Milligan et al (2014).

Efforts to improve resource efficiency in Europe and elsewhere are constrained by the fact that only some of these benefits are currently measured, valued in markets, or otherwise taken into account during public and private sector decision-making. Conventional approaches to measuring and managing economic activity do not adequately account for the range of resource stocks and associated benefit flows, in particular critical flows of ecosystem services (Stiglitz et al., 2009, Kumar, 2012). The status of resource stocks and benefit flows is not for example captured comprehensively by accounting frameworks such as the UN System of National Accounts (EC et al., 2009) or by the ubiquitous and politically influential measure of national economic activity the Gross Domestic Product.

Without holistic identification of the multiple benefits provided by resources, it is not possible to accurately assess the efficiency of resource use. Efforts have proliferated in recent years to recognise the multiple public and private benefits of resources in decision-making, and incentivise multiple actors to invest in long-term maintenance and efficient use of these benefits. Key examples of promising international efforts include the following:

- International commitments and goals - including relevant commitments in Agenda 21; Aichi Biodiversity Targets under the CBD; Jakarta Charter on Business and Biodiversity; Gaborone Declaration for Sustainability in Africa; Natural Capital Communiqué; 2012 Protocol adopted by the Global Legislators Organisation; the G8 Kobe 3 R Action Plan (OECD, 2008) and 2030 Agenda for Sustainable Development as discussed above (Milligan et al., 2014).

- $\quad$ Measurement and accounting frameworks - including The Inclusive Wealth Report and associated Inclusive Wealth Index; World Bank Adjusted Net Savings; Natural Capital Protocol for business; and UN System for EnvironmentalEconomic Accounting (SEEA). SEEA is designed to supplement the System of National Accounts, and contains internationally agreed standards for producing 
comparable statistics concerning the environment and its relationship with the economy (UN et al., 2014a, UN et al., 2014b).

- $\quad$ Knowledge and capacity building partnerships - including UN-REDD; UNHabitat; C40 Cities Climate Leadership Group; World Bank WAVES Partnership; The Economics of Ecosystems and Biodiversity (TEEB) Initiative; WBCSD and Natural Capital Coalition; and the 10YFP.

\section{Towards better governance for resource efficiency and the role of European actors}

This paper has surveyed the diverse ways in which global resources governance is beginning to respond to the urgent need to improve resource efficiency, including as subcomponent of wider efforts to improve the sustainability of resource use. These changes are apparent at local, national, regional and global scales, in both developed and developing countries. Despite considerable progress, they currently fall far short of the level of change required to achieve the international community's shared vision of sustainable development. Human activity is changing ecosystems rapidly and extensively, largely in response to increasing demands for food, fresh water, timber, fibre, and fuel (UNEP, 2012; MA, 2005). These changes have decreased flows of many ecosystem services, increased risks of nonlinear environmental change, and exacerbated poverty for some groups of people (MA, 2005). The amount of materials extracted from resources and consumed worldwide has increased dramatically in recent decades, reaching nearly 72 billion metric tonnes (Gt) in 2010, and projected to reach $100 \mathrm{Gt}$ by 2030 (OECD, 2015).

The world population is projected to reach 9.7 billion in 2050, an increase of 33\% from 2015 that is likely to be concentrated in urban regions of Africa and Asia (DESA, 2015). This increase coupled with continued economic growth in a business-as-usual mode are likely to dramatically increase pressures on and demand for resources (UNEP, 2012; Krausman et al, 2009; SERI, 2008). For example, demand for food and fibre could increase by $60 \%$ and $80-95 \%$ respectively by 2050 (FAO, 2012). Demand for water could increase by $55 \%$ over the same period (OECD, 2012).

Meeting future demand for resources in Europe and globally will inevitably require dramatic additional improvements in resource efficiency. Due to path dependencies, inertia and other biases against change, these improvements will not emerge inevitably from the operation of markets alone (UNEP, 2014b). They will need to be enabled and driven by appropriate reforms to current features of global resources governance, including continued reforms concerning the protection and definition of resourcerelated rights, management of resources across sectors, boundaries and global value chains; and recognition supported by measurement, valuation and other approaches of 
the multiple public and private benefits of resources. Figure 8 illustrates some of the key aspects of energy efficiency governance that will need to be introduced in European and other jurisdictions if the various extensively documented barriers to greater increases in energy efficiency (see IEA(2010b) and IEA (2010a), and by extension greater resource efficiency more generally, are to be addressed.

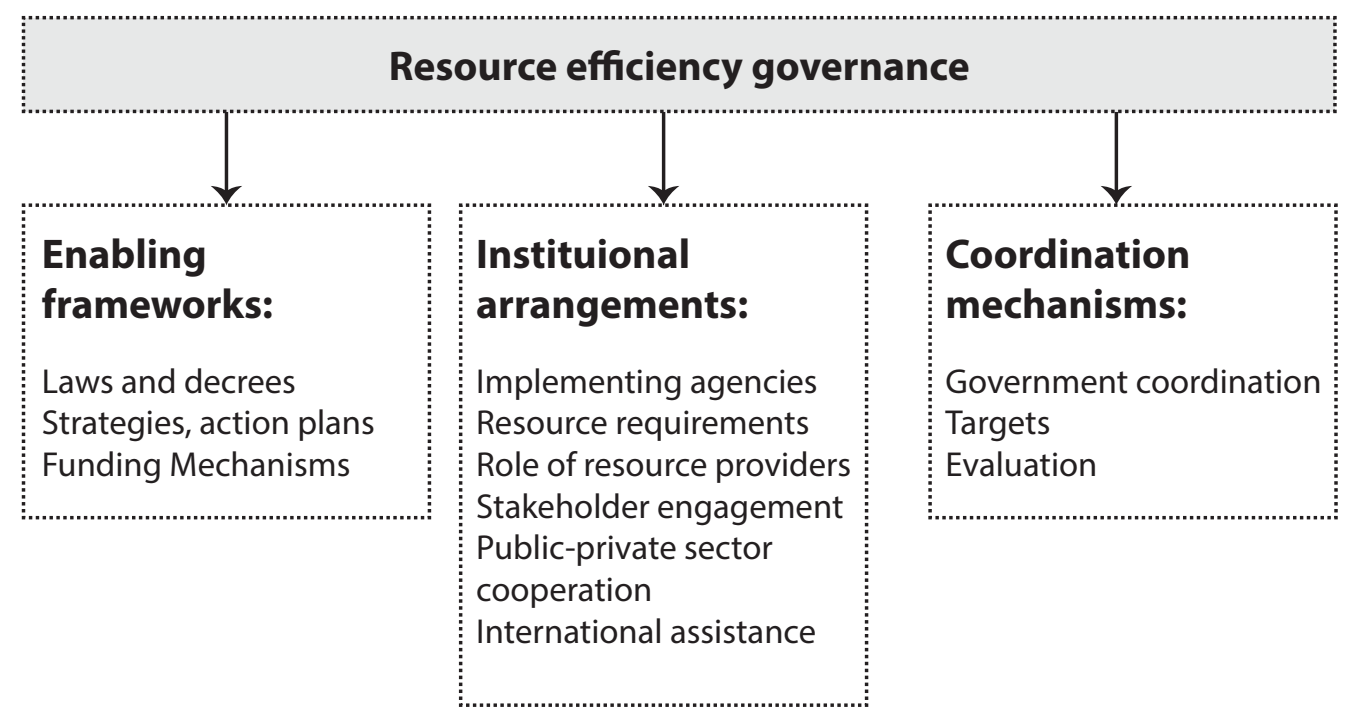

Figure 8: Key aspects of resource efficiency governance. Source: Adapted from Energy Efficiency Governance Handbook, IEA (2O1Ob) pp. 8-11

On the basis of the above considerations, our concluding reflections relating to the role of government and non-government actors in Europe are as follows:

- Efforts to remove governance constraints to resource efficiency rely on continued cooperation and diverse forms of support. This entails international and regional efforts, including commitments and goals such as the 2030 Agenda for Sustainable Development; capacity-building and research partnerships such as the 1OYFP; and the implementation at multiple scales of appropriate governance reforms. It also entails complementary national and subnational efforts - involving various parts of government and other actors, including communities and the private sector. Inclusive cross-sectoral partnerships are crucial to achieve the level of consensus and investment required to achieve lasting and effective reform, and European actors have an important global leadership role to play in championing development of such partnerships.

- There is no single 'best practice' approach to improving global governance for resource efficiency. The task is complex and specific to regional, national and local circumstances, cutting across many policies, programmes, institutions and sectors. The changes surveyed in Sections 2 and 3 above represent promising examples that may be adapted in Europe to suit different contexts, or larger or smaller scales. 
Appropriate capacity development of European governance frameworks at national, subnational and local scales, and more inclusive participatory processes at local community scales, represent important ingredients of any best practice.

- A key policy challenge for the European Union, national and subnational governments, and other actors in Europe is to expand efforts to develop and share innovative approaches concerning the governance of resource efficiency. This article has offered a glimpse of the wealth of relevant knowledge and expertise that exists in the collective experience of experts, communities, and institutions, around the world. Transnational sharing, discussion and synthesis of different approaches to resources governance enables all participating actors to benefit from the global collective experience, and overcome key barriers to change including knowledge gaps, capacity challenges, or the absence of supportive political commitment. Supported by the UNEP, the OECD, 1OYFP and others, governmental and non-government actors in Europe are, by global standards, well-resourced to support and facilitate such a process moving forward. 


\section{REFERENCES}

350.ORG. 2015. Divestment Commitments Overview [Online]. Available: http://gofossilfree.org/commitments/.

AFDB 2014. Transitioning towards Green Growth: A Framework for the African Development Bank.: African Development Bank.

AGGARWAL, S. \& ELBOW, K. 2006. Lessons Learned: Property Rights and Natural Resource Management. USAID.

AHMED, S. \& POTTER, D. M. 2006. NGOs in International Politics, Kumarian Press.

ANSEEUW, W., ALDEN WILY, L., COTULA, L. \& TAYLOR, M. 2012. Land Rights and the Rush for Land: Findings of the Global Commercial Pressures on Land Research Project. Rome: International Land Coalition.

ASDB 2008. Toward Resource-Efficiency Economies in Asia and the Pacific: Reduce, Re-use, Recycle. . Asian Development Bank.

ASDB 2015. Energy efficiency developments and potential energy savings in the Greater Mekong Subregion. . Mandaluyong City, Philippines: Asian Development Bank.

BACHE, I. \& FLINDERS, M. (eds.) 2004. Multilevel Governance, Oxford: Oxford University Press.

BAHN-WALKOWIAK, B. \& STEGER, S. 2015. Resource Targets in Europe and Worldwide: An Overview. Resources 4, 597-620.

BANKES, N. 2010. International Human Rights Law and Natural Resources Projects Within the Traditional Territories of Indigenous Peoples. Alberta Law Review, 47, 457-496.

BARMA, N. H., KAISER, K., LC, T. M. \& VIÑUELA., L. 2012. Rents to Riches? The Political Economy of Natural Resource-led Development. World Bank.

BARNES, R. 2009. Property Rights and Natural Resources, Hart Publishing.

BASLAR, K. 1998. The Concept of the Common Heritage of Mankind in International Law, Brill | Nijhoff.

BASTIDA, A., IFESI-OKOYE, A., MAHMUD, S. \& ROSS, J. 2007. Cross-Border Unitization and Joint Development Agreements: An International Law Perspective. . Houston Journal of International Law, 29, 355-422.

BEHARRY, C. \& KURITZKY, M. 2015. Going Green: Managing the Environment through International Investment Arbitration. American University International Law Review, 30, 383-429.

BENVENISTI, E. 2002. Sharing Transboundary Resources: International Law and Optimal Resource Use, Cambridge University Press.

BETSILL, M. M. \& BULKELEY, H. 2004. Transnational Networks and Global Environmental Governance: The Cities for Climate Protection Program. International Studies Quarterly, 48, 471-493.

BIERMANN, F. \& PATTBERG, P. 2008. Global Environmental Governance: Taking Stock, Moving Forward. Annual Review of Environment and Resources, 33, 277-294.

BIERMANN, F., PATTBERG, P., VAN ASSELT, H. \& ZELLI, F. 2009. The Fragmentation of Global Governance Architectures: A Framework for Analysis. Global Environmental Politics, 9, 14-40. 
BIRNIE, P., BOYLE, A. \& REDGWELL, C. 2009. International Law and the Environment, 3rd Edition., Oxford University Press.

BODANSKY, D., BRUNNÉE, J. \& HEY, E. (eds.) 2007. The Oxford Handbook of International Environmental Law, Oxford: Oxford University Press.

BOWMAN, M., DAVIES, P. \& REDGWELL, C. 2010. Lyster's International Wildlife Law, 2nd Edition., Cambridge University Press.

BRAITHWAITE, J. \& DRAHOS, P. 2000. Global Business Regulation Cambridge University Press.

CBD 1992. Convention on Biological Diversity (CBD), adopted 5 June 1992, in force 29 December 1993, 1760 UNTS 79.

CBD \& GEF 2012. Marine Spatial Planning in the Context of the Convention on Biological Diversity: A study carried out in response to CBD COP 10 decision X/29. Secretariat of the Convention on Biological Diversity (CBD) and the Scientific and Technical Advisory Panel - GEF. Technical Series No. 68. Montreal.

CGG 1995. Our Global Neighbourhood. The Report of the Commission on Global Governance, Oxford University Press.

CHARLES, A. 2012. People, oceans and scale: governance, livelihoods and climate change adaptation in marine social-ecological systems. Current Opinion in Environmental Sustainability, 4, 351-357.

CIA. 2016. Central Intelligence Agency. The World Factbook [Online]. Available: https://http://www.cia.gov/library/publications/the-world-factbook/.

COTULA, L. 2013. The Great African Land Grab? Agricultural Investments and the Global Food System, Zed Books.

COTULA, L., OYA, C., CODJOE, E. A., EID, A., KAKRABA-AMPEH, M., KEELEY, J., KIDEWA, A. L., MAKWARIMBA, M., SEIDE, W. M., NASHA, W. O., ASARE, R. O. \& RIZZO, M. 2014. Testing Claims about Large Land Deals in Africa: Findings from a Multi-Country Study. Journal of Development Studies, 50, 903-925.

COTULA, L., VERMEULEN, S., LEONARD, R. \& KEELEY, J. 2009. Land grab or development opportunity? Agricultural investment and international land deals in Africa. . FAO / International Institute for Environment and Development / International Fund for Agricultural Development.

CRAIK, N. 2011. The International Law of Environmental Impact Assessment: Process, Substance and Integration. , Cambridge University Press.

DARBY, S. 2010. Natural resource governance: New frontiers in transparency and accountability. Transparency Accountability Initiative.

DEININGER, K. \& ALI, D. A. 2008. Do Overlapping Land Rights Reduce Agricultural Investment? Evidence from Uganda. American Journal of Agricultural Economics, 90, 869-882.

DICKEN, P. 2011. Global shift: mapping the changing contours of the world economy, 6th edition., New York, The Guilford Press.

DINGWERTH, K. \& PATTBERG, P. 2006. Global Governance as a Perspective on World Politics. Global Governance: A Review of Multilateralism and International Organizations, 12, 185-203.

DOLAN, C. \& HUMPHREY, J. 2000. Governance and Trade in Fresh Vegetables: The Impact of UK Supermarkets on the African Horticulture Industry. Journal of Development Studies, 37, 147. 
DONAHUE, J. D. \& NYE JR., J. S. (eds.) 200o. Governance in a Globalizing World: Brookings Institution,.

DUDLEY, N. (ed.) 2008. Guidelines for applying protected area management categories., Gland, Switzerland: IUCN.

EBRD 2014. European Bank for Reconstruction and Development Annual Report 2014. European Bank for Reconstruction and Development

EC 2011a. Commission Staff Working Paper: Analysis associated with the Roadmap to a Resource Efficient Europe Parts I and II. Brussels, 20.9.2011 SEC(2011) 1067 final.: European Commission.

EC 2011b. A resource-efficient Europe - Flagship initiative under the Europe 2020 Strategy. Communication from the Commission to the European Parliament, The Council, The European Economic and Social Committee and the Committee of the Regions. Brussels, 26.1.2011 $\operatorname{COM}(2011) 21$.

EC. 2015. EU Resource Efficiency Scoreboard 2015 [Online]. Available: http://ec.europa.eu/environment/resource_efficiency/targets_indicators/scoreboard/pdf/EU Resource Efficiency Scoreboard 2015.pdf.

EC, IMF, OECD, UN \& BANK, W. 2009. System of National Accounts 2008.

EEA 2011. Global governance - the rise of non-state actors: A background report for the SOER 2010 assessment of global megatrends. EEA Technical report No 4/2011.: European Environment Agency.

ELLIS, F. \& BIGGS, S. 2001. Evolving Themes in Rural Development 1950s-2000s. Development Policy Review, 19, 437-448.

FAO 2012. Voluntary Guidelines on the Responsible Governance of Tenure of Land, Fisheries and Forests in the Context of National Food Security

FRITSCHE, U., GAVILAN, I. \& LEAGNAVAR, P. 2013. Elaborating the International Discussion on Resource Efficiency (ENTIRE): Part I: Resource Efficiency Policies in Various Countries - Annex Report. Prepared for IFAD with funding from BMBF. Darmstadt, London, Paris, .

GALAZ, V., MOBERG, F., OLSSON, E. K., PAGLIA, E. \& PARKER, C. 2010. Institutional and Political Leadership Dimensions of Cascading Ecological Crises. Public Administration, 89, 361-380.

GALLAGHER, K. \& SHRESTHA, E. 2011. Investment Treaty Arbitration and Developing Countries: A ReAppraisal. Journal of World investment and Trade, 12, 919-928.

GEMMILL, B. \& BAMIDELE-IZU, A. 2002. The Role of NGOs and Civil Society in Global Environmental Governance. In: ESTY, D. C. \& IVANOVA, M. H. (eds.) Global Environmental Governance: Options and Opportunities. Yale Center for Environmental Law \& Policy.

GEOSCIENCES AUSTRALIA, Maritime Boundary Definitions, 2017, http://www.ga.gov.au/scientifictopics/marine/jurisdiction/maritime-boundary-definitions.

GEREFFI, G., HUMPHREY, J. \& STURGEON, T. 2005. The governance of global value chains. . Review of International Political Economy 12, 78-104.

GHAUS-PASHA, A. 2005. The Role of Civil Society Organisations in Governance. 6th Global Forum on Reinventing Government Towards Participatory and Transparent Governance, 24 - 27 May 2005. Seoul, Republic of Korea.

GILSON, G. 2012. Corporate Social Responsibility in the extractive industries: Experiences from developing countries. . Resources Policy, 37, 131-137. 
GORDON, K. \& POHL, J. 2011. Environmental Concerns in International Investment Agreements: A Survey. OECD Working Papers on International Investment, 2011/01, OECD Publishing.

GTZ, CSCP \& WUPPERTAL INSTITUTE FOR CLIMATE, E. A. E. 2006. Policy Instruments for Resource Efficiency: Towards Sustainable Consumption and Production.

HANNA, S., FOLKE, C. \& MALER, K.-G. (eds.) 1996. Rights to Nature: Ecological, Economic, Cultural, and Political Principles of Institutions for the Environment: Island Press.

HARRIS, P. G. (ed.) 2016. Routledge Handbook of Global Environmental Politics: Routledge

HAUFLER, V. 2010. Disclosure as Governance: The Extractive Industries Transparency Initiative and Resource Management in the Developing World. Global Environmental Politics, 10, 53-73.

HENSON, S. \& REARDON, T. 2005. Private agri-food standards: Implications for food policy and the agri-food system Food Policy, 30, 241-253.

HOLDEN, J. \& PAGEL, M. 2013. Transnational land acquisitions: What are the drivers, levels, and destinations of recent transnational land acquisitions? EPS-PEAKS Consortium.

HUNTER, D., SALZMAN, J. \& ZAELKE, D. 2015. International Environmental Law and Policy, Revised 5th Edition, Foundation Press.

HUTH, P. K. 1998. Standing Your Ground: Territorial Disputes and International Conflict, The University of Michigan Press.

IADB 2015. Inter-American Development Bank (IADB) Energy Sector Framework Document, November 2015.

IEA 2010a. Energy Efficiency Governance. Paris: International Energy Agency.

IEA 2010b. Energy Efficiency Governance Handbook. Paris: International Energy Agency.

IFAD 2011. International Fund for Agricultural Development (IFAD). Rural Poverty Report 2011.

IPCC 2014a. Climate Change 2014: Impacts, Adaptation and Vulnerability. Contribution of Working Group II to the Fifth Assessment Report of the Intergovernmental Panel on Climate Change, Cambridge, United Kingdom, Cambridge University Press.

IPCC 2014b. Climate Change 2014: Mitigation of Climate Change. Contribution of Working Group III to the Fifth Assessment Report of the Intergovernmental Panel on Climate Change, Cambridge, United Kingdom, Cambridge University Press.

ITU 2015. International Telecommunication Union Yearbook of Statistics.

IUCN 2014. International Union for Conservation of Nature Annual Report 2014.

KAPLINSKY, R. \& MORRIS, M. 2001. A Handbook for Value Chain Research. Ottawa: International Development Research Centre.

KIM, R. E. 2013. The emergent network structure of the multilateral environmental agreement system. Global Environmental Change, 23, 980-991.

KLIOT, N., SHMUELI, D. \& SHAMIR, U. 2001. Institutions for management of transboundary water resources: their nature, characteristics and shortcomings. Water Policy, 3, 229-255.

KOLSTAD, I. \& SØREIDE, T. 2009. Corruption in natural resource management: Implications for policy makers. Resources Policy, 34, 214-226. 
KOLSTAD, I. \& WIIG, A. 2009. Is Transparency the Key to Reducing Corruption in Resource-Rich Countries? World Development, 37, 521-532.

KOWALSKI, P., BÜGE, M., SZTAJEROWSKA, M. \& EGELAND, M. 2013. State-Owned Enterprises: Trade Effects and Policy Implications. OECD Trade Policy Papers No. 147, 2013.

KUMAR, P. (ed.) 2012. The economics of ecosystems and biodiversity: ecological and economic foundations, Oxford, New York: Routledge Press.

KURIAN, M. \& ARDAKANIAN, R. (eds.) 2015. Governing the Nexus: Water, Soils and Waste Resources Considering Global Change: UNU/Springer.

LEE, J. S. H., JAAFAR, Z., TAN, A. K. J., CARRASCO, L. R., EWING, J. J., BICKFORD, D. P., WEBB, E. L. \& $\mathrm{KOH}, \mathrm{L}$. P. 2016. Toward clearer skies: Challenges in regulating transboundary haze in Southeast Asia. Environmental Science \& Policy, 55, Part 1, 87-95.

LEITE, C. \& WEIDMANN, J. 1999. Does Mother Nature Corrupt? Natural Resources, Corruption and Economic Growth. International Monetary Fund Working Paper WP/99/85.

LEVY, D. L. \& NEWELL, P. J. 2004. The Business of Global Environmental Governance, MIT Press

LIM, B. \& SPANGER-SIEGFRIED, E. (eds.) 2004. Adaptation Policy Frameworks for Climate Change: Developing Strategies, Policies and Measures: UNDP / CUP.

LIU, Q., LU, R. \& MA, X. 2015. Corruption, Financial Resources and Exports. Review of International Economics, 23, 1023-1043.

MACE, G. M., HAILS, R. S., CRYLE, P., HARLOW, J. \& CLARKE, S. J. 2015. REVIEW: Towards a risk register for natural capital. Journal of Applied Ecology, 52, 641-653.

MCHARG, A., BARTON, B., BRADBROOK, A. \& GOLDEN, L. 2010. Property and the Law in Energy and Natural Resources Oxford, Oxford University Press.

MEA 2005. Millennium Ecosystem Assessment (2005). Ecosystems and Human Well-being: Synthesis. , Washington, DC., Island Press.

MILLIGAN, B. 2012. Legal and policy options for the provisional joint management of maritime spaces subject to overlapping jurisdictional claims University of Wollongong.

MILLIGAN, B., TERAMA, E., JIMENEZ-AYBAR, R. \& EKINS, P. 2014. GLOBE Natural Capital Accounting Study, 2nd Edition. GLOBE International and University College London.

MIRANDA, L. A. 2012. The Role of International Law in Intrastate Natural Resources Allocation: Sovereignty, Human Rights, and People-Based Development. Vanderbilt Journal of Transnational Law, 45, 785-840.

MITCHELL, L. 2013. Natural Resource Contracts: A Practical Guide. Environmental Law Alliance Worldwide (ELAW).

MORRISON, J. \& ROHT-ARRIAZA, N. 2007. Private and Quasi-Private Standard Setting. In: BODANSKY, D., BRUNNÉE, J. \& HEY, E. (eds.) The Oxford Handbook of International Environmental Law. Oxford: Oxford University Press.

NEWIG, J. \& FRITSCH, O. 2009. Environmental Governance: Participatory, Multi-level - and Effective? Environmental Policy and Governance, 19, 197-214.

NIKOLAEVA, R. \& BICHO, M. 2011. The role of institutional and reputational factors in the voluntary adoption of corporate social responsibility reporting standards. Journal of the Academy of Marketing Science, 39, 136-157. 
NRGI 2014. Natural Resource Charter, 2nd Edition. Natural Resource Governance Institute.

OECD 2006. The Challenge of Capacity Development: Working Towards Good Practice. DAC Guidelines and Reference Series.

OECD 2008. Resource Productivity in the G8 and the OECD: A Report in the Framework of the Kobe $3 \mathrm{R}$ Action Plan.

OECD 2012. Green Growth and Developing Countries: Consultation Draft.

OECD 2013. Issues Paper on Corruption and Economic Growth. G20 Leaders Summit, St Petersburg, September 2013.

OECD 2015. Policy Framework for Investment - 2015 Edition Paris: OECD Publishing.

OECD, WORLD BANK \& UN 2012. Incorporating Green Growth and Sustainable Development Policies into Structural Reform Agendas. Report prepared for the G20 Summit, Los Cabos, 18-19 June 2012.

OECD, WTO \& BANK, W. 2014. Global Value Chains: Challenges, Opportunities, and Implications for Policy.

PALMER, D. 2012. Improving the Governance of Tenure of Land, Fisheries and Forests. FAO Land Tenure Journal, 1.

PATTBERG, P. 2005. What Role for Private Rule-Making in Global Environmental Governance? Analysing the Forest Stewardship Council (FSC). International Environmental Agreements, 5, 175-189.

PATTBERG, P. 2007. Private Institutions and Global Governance: The New Politics of Environmental Sustainability, Edward Elgar.

PRESCOTT, V. \& SCHOFIELD, C. 2004. The Maritime Political Boundaries of the World, 2nd Edition, Brill | Nijhoff.

RINGLER, C., BHADURI, A. \& LAW, R. 2013. The nexus across water, energy, land and food (WELF): potential for improved resource use efficiency? . Current Opinion in Environmental Sustainability, 5, 617-624.

ROBBINS, P. 2000. The rotten institution: corruption in natural resource management. Political Geography, 19, 423-443.

ROCKSTRÖM, J., STEFFEN, W., NOONE, K., PERSSON, A., CHAPIN, F. S., LAMBIN, E. F., LENTON, T. M., SCHEFFER, M., FOLKE, C., SCHELLNHUBER, H. J., NYKVIST, B., DE WIT, C. A., HUGHES, T., VAN DER LEEUW, S., RODHE, H., SORLIN, S., SNYDER, P. K., COSTANZA, R., SVEDIN, U., FALKENMARK, M., KARLBERG, L., CORELL, R. W., FABRY, V. J., HANSEN, J., WALKER, B., LIVERMAN, D., RICHARDSON, K., CRUTZEN, P. \& FOLEY, J. A. 2009. A safe operating space for humanity. Nature, $461,472-475$.

ROSE, G. \& MILLIGAN, B. 2009. Law for the Management of Antarctic Marine Living Resources: From Normative Conflicts towards Integrated Governance? Yearbook of International Environmental Law, 20, 41-87.

ROTHWELL, D. 1996. The Polar Regions and the Development of International Law. , Cambridge University Press.

RRI 2015. Who Owns the World's Land? A Global Baseline of Formally Recognized Indigenous and Community Land Rights. Rights and Resources Initiative. 
RRI 2016. Closing the Gap: Strategies and scale needed to secure rights and save forests. Rights and Resources Initiative Annual Review 2015-2016. Rights and Resources Initiative.

RUHL, J. B., KRAFT, S. \& LANT, C. 2007. The Law and Policy of Ecosystem Services, Island Press.

RUSSELL, D. \& VANDERZWAAG, D. (eds.) 2010. Recasting Transboundary Fisheries Management Arrangements in Light of Sustainability Principles: Canadian and International Perspectives.: Marinus Nijhoff / Brill.

SALACUSE, J. 2015. The Law of Investment Treaties, 2nd Edition. , Oxford University Press.

SANDWITH, T., SHINE, C., HAMILTON, L. \& SHEPPARD, D. 2001. Transboundary Protected Areas for Peace and Co-operation. IUCN World Commission on Protected Areas, Best Practice Protected Area Guidelines Series No. 7.

SAUVANT, K. P. 2015. The Negotiations of the United Nations Code of Conduct on Transnational Corporations: Experience and Lessons Learned. The Journal of World Investment \&amp; Trade, $16,11-87$.

SCHLAGER, E. \& OSTROM, E. 1992. Property-rights regimes and natural resources: A conceptual analysis. Land Economics, 68, 249.

SCHOFIELD, C. 2011. The delimitation of maritime boundaries: an incomplete mosaic. In: WASTLWALTER, D. (ed.) The Ashgate Research Companion to Border Studies.

SCHOFIELD, C. (ed.) 2012. Maritime Energy Resources in Asia: Legal Regimes and Cooperation. National Bureau of Asian Research Reports.

SCHRIJVER, N. 1997. Sovereignty over natural resources: balancing rights and duties, Cambridge University Press.

SMALLER, C. 2014. The IISD Guide to Negotiating Investment Contracts for Farmland and Water. International Institute for Sustainable Development (IISD).

SPAR, D. \& LA MURE, L. 2003. The Power of Activism: Assessing the Impact of NGOs on Global Business. California management review, 45, 78-101.

SPETH, J. G. \& HAAS, P. 2009. Global Environmental Governance: Foundations of Contemporary Environmental Studies., Island Press.

STIGLITZ, J. E., SEN, A. \& FITOUSSI, J. P. 2009. Report of the commission on the measurement of economic performance and social progress.

STOLTON, S., SHADIE, P. \& DUDLEY, N. 2013. IUCN WCPA Best practice guidance on recognising protected areas and assigning management categories and governance types, Gland, Switzerland, IUCN.

SUÁREZ, S., OSORIO, L. \& LANGFORD, M. 2009. Voluntary Guidelines for Good Governance in Land and Natural Resource Tenure: Civil Society Perspectives, FAO Land Tenure Working Paper 8.

TIENHAARA, K. 2011. Regulatory chill and the threat of arbitration: A view from political science. In: BROWN, C. \& MILES, K. (eds.) Evolution in Investment Treaty Law and Arbitration. Cambridge University Press.

TOMPKINS, E. 2008. Development Pressures and Management Considerations in Small Caribbean Islands' Coastal Zones. CSERGE Working Paper ECM 03-08.

TOULMIN, C. \& QUAN, J. (eds.) 2000. Evolving Land Rights, Policy and Tenure in Africa: IIED / DFID. 
UK-NCC 2013. The State of Natural Capital: Towards a framework for measurement and valuation.: UK Natural Capital Committee (UK-NCC).

UN 2015. Transforming our world: the 2030 agenda for sustainable development. New York: United Nations.

UN, COMMISSION, E., OECD \& BANK, W. 2014a. System of Environmental-Economic Accounting 2012 Experimental Ecosystem Accounting. .

UN, EU, FAO, IMF, OECD \& WORLD BANK 2014b. System of Environmental-Economic Accounting 2012 Central Framework.

UN-ESCAP 2013. The Status of the Water-Food-Energy Nexus in Asia and the Pacific. Discussion Paper. United Nations Economic and Social Commission for Asia and the Pacific.

UN-HABITAT 2009. Planning Sustainable Cities: Global Report on Human Settlements 2009. United Nations Human Settlements Programme, Earthscan.

UN-WATER 2008. Transboundary Waters: Sharing Benefits, Sharing Responsibilities. Thematic Paper.

UNCLOS 1982. United Nations Convention of the Law of the Sea (UNCLOS), adopted 10 December 1982, in force 16 November 1994, 1833 UNTS 397.

UNCTAD 2009. United Nations Conference on Trade and Development. World Investment Report 2009: Transnational Corporations, Agricultural Production, and Development. UNCTAD/WIR/2009.

UNCTAD 2014. World Investment Report 2014: Investing in the SDGs: An Action Plan. UNCTAD/WIR/2014.: United Nations Conference on Trade and Development.

UNCTAD 2015. United Nations Conference on Trade and Development World Investment Report 2015: Reforming International Investment Governance. UNCTAD/WIR/2015.

UNDESA 2012. A guidebook to the Green Economy. Issue 3: exploring green economy policies and international experience with national strategies.

UNDESA 2015. Global Sustainable Development Report 2015 Edition. United Nations Division of Economic and Social Affairs.

UNDP 2009. Capacity Development: A UNDP Primer. United Nations Development Programme.

UNDP 2014. United Nations Development Programme Global Anti-Corruption Initiative (GAIN) 20142017.

UNEP 2011. Taking Steps toward Marine and Coastal Ecosystem-Based Management - An Introductory Guide.

UNEP 2012a. The Environmental Dimension of IFSD. UNEP Division of Environmental Law and Conventions Issues Brief \# 2.

UNEP 2012b. Measuring water use in a green economy, A Report of the Working Group on Water Efficiency to the International Resource Panel. McGlade, J., Werner, B., Young, M., Matlock, M., Jefferies, D., Sonnemann, G., Aldaya, M., Pfister, S., Berger, M., Farell, C., Hyde, K., Wackernagel, M., Hoekstra, A., Mathews, R., Liu, J., Ercin, E., Weber, J.L., Alfieri, A., Martinez-Lagunes, R., Edens, B., Schulte, P., von Wirén-Lehr, S., Gee, D.

UNEP 2014a. Assessing Global Land Use: Balancing Consumption with Sustainable Supply. A Report of the Working Group on Land and Soils of the International Resource Panel. . 
UNEP 2014b. Decoupling 2: technologies, opportunities and policy options. A report of the Working Group on Decoupling to the International Resources Panel. .

UNEP 2015. Policy Coherence of the Sustainable Development Goals: a Natural Resource Perspective. Paris: UNEP.

UNESC 2015a. Terms of reference for the Inter-agency Expert Group on Sustainable Development Goal Indicators. At http://unstats.un.org/. .

UNESC 2015b. UN Economic and Social Council (ESC) Report to the Inter-Agency and Expert Group on Sustainable Development Goal Indicators. 17 December 2015, E/CN.3/2016/2.

UNFT 2012. United Nations Interagency Framework Team for Preventive Action (UNFT) Toolkit and Guidance for Preventing and Managing Land and Natural Resources Conflict: Land and Conflict, 2012.

UNGA 1962. Permanent Sovereignty over Natural Resources, G.A. res. 1803 (XVII), 17 U.N. GAOR Supp. (No.17) at 15, U.N. Doc. A/5217 (1962).

VAN HARTEN, G. 2007. Investment Treaty Arbitration and Public Law, Oxford, Oxford University Press.

VANCLAY, F., ESTEVES, A. M., AUCAMP, I. \& FRANCKS, D. M. 2015. Social Impact Assessment: Guidance for assessing and managing the social impacts of projects. . International Association for Impact Assessment.

VIET, P., LARSEN, G. \& EASTON, C. 2013. Overlapping Property Rights: When Rights to Natural Resources Conflict with Rights to Land. World Resources Institute / USAID.

WARNER, R. 2009. Protecting the Oceans Beyond National Jurisdiction: Strengthening the International Legal Framework, Brill | Nijhoff.

WEAVER, J. L. \& ASMUS, D. F. 2006. Unitizing Oil and Gas Fields Around the World: A comparative Analysis of National Laws and Private Contracts. Houston Journal of International Law, 28, 3198.

WEIBUST, I. \& MEADOWCROFT, J. (eds.) 2014. Multilevel Environmental Governance: Managing Water and Climate Change in Europe and North America: Edward Elgar.

WEISS, T. G. \& THAKUR, R. 2010. Global Governance and the UN: An Unfinished Journey. , Indiana University Press.

WEISSBRODT, D. \& KRUGER, M. 2003. Norms on the Responsibilities of Transnational Corporations and Other Business Enterprises with Regard to Human Rights. The American Journal of International Law, 97, 901-922.

WEST, J., SCHANDL, H., HEYENGA, S. \& CHEN, S. 2013. Resource Efficiency: Economics and Outlook for China. Bangkok, Thailand: UNEP.

WTO 1994. Agreement Establishing the World Trade Organization, 15 April 1994, Preamble.

WTO 2014. World Trade Report 2014. Trade and development: recent trends and the role of the WTO. World Trade Organisation.

WTO. 2015. World Trade Organisation. Environment: Issues, Sustainable Development [Online]. Available: https://http://www.wto.org/english/tratop_e/envir_e/sust_dev_e.htm.

WWAP 2015. The United Nations World Water Development Report 2015: water for a sustainable world. Paris, France: UNESCO. 
YANDLE, T. 2007. Understanding the consequences of property rights mismatches: a case study of New Zealand's marine resources. Ecology and Society 12.

YOUNG, H. \& GOLDMAN, L. (eds.) 2015. Livelihoods, Natural Resources, and Post-Conflict Peacebuilding: Routledge.

YOUNG, O. R. (ed.) 1997. Global Governance: Drawing Insights from the Environmental Experience: MIT Press.

YOUNG, O. R., KING, L. A. \& SCHROEDER, H. 2008. Institutions and Environmental Change: Principal Findings, Applications and Research Frontiers, MIT Press

ZILLMAN, D. M., LUCAS, A. \& PRING, G. R. (eds.) 2002. Human Rights in Natural Resource Development: Public Participation in the Sustainable Development of Mining and Energy Resources, Oxford: Oxford University Press. 